\title{
Cultural Studies as a Didactic Means of Improving Intercultural Language Education
}

\author{
Victoria V. Safonova
}

Doctor of Pedagogical Sciences, professor at the Department of Foreign Languages and Regional Studies.

Lomonosov Moscow State University, Moscow, Russian Federation

\begin{abstract}
Though the issues of integrating cultural studies in language education are often raised in FLT scholarly works (M. Byram\& V. Esarte-Sarries, G. Zarate and others), but the question arises what kind of interdisciplinary cultural studies and for what didactic purposes is really needed at different levels of university education. The paper starts with looking at and showing the differences between the following concepts: "cultural studies as a branch of culturology (science of culture)", "cultural studies as an inseparable part of modern language pedagogy" and "Cultural Studies as a university subject" with the view to their didactic potential, aims \& outcomes as a means of cultural education. The author goes on with giving an insight into the essential characteristics of the three types of cultural studies /CS/ under consideration and then focuses on the CS as a branch of language pedagogy \& CS as a university subject, discussing their didactic values for modelling appropriate multi-level intercultural education though all the languages studied and co-learnt at university. The system of interrelated didactic principles of designing culture-oriented educational programmes, syllabuses and courses that is outlined in the paper includes such principles as the principles of the dialogue of cultures \& civilizations, creating didactically appropriate educational space problem-oriented learning environment.
\end{abstract}

Keywords: cultural studies, language pedagogy, multi-level pluricultural education, intercultural communicative competence, dialogue of cultures and civilisations, didactic appropriateness of educational environment, problem-oriented learning environment.

\section{Introduction}

In today's globalised world, multicultural and multilingual, the individual's ability to act in an international context seems to be one of the essential characteristics of successful people (Clawson, 2014; Earley \& Mosakowski, 2016) in different social strata and not only belonging to the Establishment. But what does it mean to be able to act in an international context? Such a person is thought to be commutatively and culturally competent enough to participate and co-operate with other people in intercultural communication. In other words, s/he should become an intercultural speaker (Kramsch,1998) who has gained a sociocultural competence that in a globalised world makes him or her capable of:

- $\quad$ observing and identifying sociocultural differences in the way of thinking and styles of life of other people representing different ethnic/national and/or political and/or religious groups, different social groups in a stratified society;

- interacting and cooperating with other people from a variety of ethnic/national, political/geopolitical, religious, social backgrounds, being aware and respectful of different cultural values, communication schemata and patterns of communicative behaviour;

- $\quad$ adapting to cultural environments of modern civilizations and geopolitical communities, being flexible in his or her ways of thinking about a variety of cognitive styles and communication patterns of behaviour;

- presenting his or her own culture in intercultural circumstances (taking into consideration the sociocultural context of communication interaction, sociocultural characteristics of communication partners) and delivering his or her message in terms linguistically and culturally understandable to his or her communication partners;

- $\quad$ foreseeing possible cultural misunderstandings leading to communicative barriers that can distort or even destroy intercultural communication; 
- $\quad$ being an effective cultural mediator (CEFR, 2001) who can help to develop understanding and co-operation between people with different ethnic/national, political/geopolitical, religious, social backgrounds or to restore the communication between them in case it has been destroyed;

- finding appropriate and reliable sociocultural information for cultural self-education in the area of intercultural communication and using appropriate ways of learning about other language-and-culture communities (Safonova,1996).

Nobody denies that universities can provide interdisciplinary cooperation and interdisciplinary basis for cultivating intercultural speakers (Kramsch,1998) or cross-cultural encounters (Morgan, 1998) or cultural mediators (CEFR, 2001) through a didactical integration of Cultural. Studies and language courses. The Routledge Encyclopedia of Language Teaching and Learning in the entry related to the Cultural Studies introduces Cultural Studies in the following way;"Cultural Studies is an umbrella term for multi- or interdisciplinary analysis of cultural phenomena (products, processes, problematic) which was first used and developed in Britain and has spread to many parts of the world over the last thirty years" (Routledge Encyclopedia of Language Teaching and Learning,2004:162). And can we really fully agree nowadays that cultural studies is always nothing else, but multi- or interdisciplinary analysis of cultural phenomena with its focus mostly on its research method. But what about Cultural Studies as an academic discipline in the system of teaching Humanities? Once Hartley put the following questions: How does Cultural Studies address the reader? How does it create a large, transnational multidisciplinary readership (Hartley, 2003:13)? One more question could be added here: What cultural studies do modern educators mean and need for being able to design a model of cultivating effective intercultural speakers and peacemakers?

In this paper, I would like to have a look at Cultural Studies as an academic research field in cultorology, didacticallyoriented Cultural Studies as an academic research field in language pedagogy and Cultural Studies as a school/university subject or discipline in pluricultural education, and what do they have in common and in what way do they differ from each other

\section{Cultural Studies as a Branch of Culturology.}

- $\quad$ Traditionally, Cultural Studies is viewed as a branch of culturology in Russia (Rozhdestvensky,1969; Culturology. XX century,1998; Rozhdestvensky, 1996). It is considered to be a multidisciplinary field of research that is nowadays multifunctional in its scope. Cultural Studies as a branch of culturology in Russia, first, studies in what way a variety of life styles in society is reflected in social values, norms, traditions and customs, historical memory (ethnic or super ethnic / national, or regional, or even continental); how cultural heritage, cultural identity and mentality of human beings are preserved, protected and shared by members of particular language-and-culture communities \& subcultural groups; how variable they may be in the life of modern countries, their peoples and languages (operating in different cultures).

Secondly, it examines traditional socio-cultural values of the spiritual, physical and material cultures of human communities (Rozhdestvensky, 1996) and identifies the appearance of possible changes in them which are articulated in human behavioral codes, communicative schemata and cognitive perception of world sociocultural changes that have already been observed in linguacultures.

And thirdly, it gains a scientific understanding of:

- sociocultural portraits of countries, their languages and cultural communities, social strata in terms of social values, historical memory and its historical background, cultural heritage and contributions to the World culture, cultural perception of their country and other countries, attitudes to globalization and cultural identification;

- socio-cultural norms of human behavior in monocultural or multicultural communities, internal (within cultural and linguistic environment of a particular community in society) and external (in case of interaction between members of different cultural and linguistic communities);

- linguocultural aspects of intercultural communication;

- types of cultural, sociolinguistic and linguocultural barriers destroying communication that may lead not only to cultural misunderstandings, but to killing communicative interaction as such between its interlocutors. 


\section{Cultural Studies as a Field of Research in Language Pedagogy.}

Cultural Studies as a field of research in language pedagogy has been intensely developed since the 1990s mostly in foreign language teaching and learning, because language teaching, as M. Byram puts it, has always and inevitably meant "language and culture teaching"( Byram \& Esarte-Saaries,1990: 5).It is interesting to note meanwhile that that it was Robert Lado who first put forward an idea of interrelating language and culture in teaching a foreign/second language in 1957 (Lado,1957), but in the 1960s cultureoriented approaches to foreign language teaching were not and could not be developed due to a number of societal and methodological reasons, At that time the Western world was only on the way of politicoeconomic and ideological integration, so social needs for various intercultural interactions were not so much strongly felt in comparison with the 1990s of the previous century.

But, as soon as world globalization has become an essential characteristic of human societies nearly in all corners of the planet and more and more people have started being involved in endless intercultural interactions it was a culture-oriented language methodology that started entering the stage of language education. Since the 1990s a great number of culture-oriented approaches to language teaching have been developed in language pedagogy and implemented in language education of some European countries. Among them are such as: an intercultural approach (Corbett, 2003), an ethnographic approach (Byran \& Flemig,1998; Barro, Jordan, Roberts,1998;. Barro \& Grimm,1998), a culture-sensitive approach (Holliday,1994), a sociocultural approach (Safonova,1991,1996), a transcultural approach (Meyer,1991; Brady \& Shinohara,2000), a pluricultural and plurilingual approach (Bernaus, 2007). And Cultural Studies has become a key element in ethnographic, sociocultural and intercultural approaches (Byram, EsarteSarries,1991,1997; Safonova,1991,1996; Wadham-Smith,1995).

It is worth mentioning here that the approaches mentioned above differ greatly from one another in terms of their understanding what kind of intercultural communication should and may be didactically facilitated in language teaching. For example, within an ethnographical approach (Byran \& Flemig,1998) the educational focus is mostly cross-ethnic, whereas in a sociocultural approach it is pluricultural. So crossethnic or pluricultural?

It is a well-known fact that in modern globalised world we communicate in a foreign language not only with native speakers, but with non-native-speakers as well, especially if this or that foreign language functions as a language of international communication (e.g. English, French, Russian). And in different types of communication not only do intercultural interlocutors consciously or subconsciously demonstrate their ethnic or national cultural affiliation, but their interaction is also framed by their religious, ideological (including geopolitical) backgrounds, regional and continental beliefs and values. All that strongly affect their cultural code and patterns of their verbal and non-verbal behaviour and, consequently, it influences their wish to communicate with each other, the flow of communication and even the appearance of cultural barriers.

And that explains why in the context of a sociocultural approach to teaching international languages (Safonova,1991,1996) intercultural communication is viewed as an interaction between interlocutors or writers who identify themselves or are identified by other people as representatives belonging not only to different ethnic or super ethnic (national) communities (considerably religiously biased or vice versa with dominating atheistic beliefs in their societies), but to this or that degree they may also demonstrate their belonging to particular regional and/or continental and/or geopolitical communities,or even to a particular civilization layer, as well as their belonging to social subcultures (cultures of different social strata, professional groups, gender cultures, culture of the young \& the old etc.). And this variety of cultures and subcultures manifest itself in the communicative codes, manners of intercultural speakers and writers, their communicative and cognitive schemata of behaviour. In other words, in situations of intercultural interaction speakers or writers act as bearers of a particular set of cultures and subcultures and, thus, in this way they would differ from each other in terms of values, beliefs, world view orientations, lifestyles, behavioral models of verbal and non-verbal communication (Safonova,2001:19). 
It is important to note that any effective intercultural communication in the globalised world needs not only its interlocutors' awareness of cultural and subcultural differences, but of their possible cultural links and what their cultures may have in common, because sometimes the cross-cultural element is too much overemphasized, for example, in teaching languages. And modern language pedagogy is trying to find a certain balance between the universal and the specific in cultures and even subcultures. Cultural Studies as a research field in language pedagogy has got its own distinguishing characteristics (in comparison with Cultural Studies as a branch of culturology). They may be identified as follows:

1. Pedagogy-oriented cultural studies is expected to establish an appropriate theoretical basis for pluricultural development of the language learner as an intercultural speaker or writer.

2. One of its main concerns is a didactic description of multilevel pluricultural and plurilingual competences (Coste, Moore \& Zarate, 2009:21) of the individual involved in intercultural communication and being able to act in its situations, overcoming its communicative and cultural barriers.

3. It develops a system of principles of developing pluricultural competence in the university classroom like a principle of teaching languages in the context of dialogue of cultures and civilisations (Safonova,1991).

4.It explores and suggests didactic options for cultures-oriented language education and self-education through all co-learnt languages with the view to the essential characteristics of modern intercultural communication (including cultural / cross-cultural barriers to it and how to overcome them in a globalised world), learners' needs as intercultural speakers / writers, sociocultural context of teaching and learning languages in a particular country, learners' sociocultural portrait in terms of their cultural views, values and beliefs, their communicative and intellectual powers.

5. It studies the powers of language education as an instrument of the individual's socialisation.

6 . It develops Linguocultural Studies as an inseparable part of Cultural Studies related to the field of language acquisition.

7. It develops methods of sociocultural analysis of teaching materials, the cultural characteristics and influences of the latter (positive or negative ones) on the learner's ability to act as an intercultural speaker I writer. It is also important to mention that cultural studies as a research field in language pedagogy also includes researches in Linguocultural Studies on cross-cultural or multi-cultural basis.

\section{Cultural Studies as a university subject}

- Cultural Studies as a university subject is a multidisciplinary course, integrating historical, sociological, aesthetic, literary, anthropological, ethnographic. psychological and communicative knowledge of intercultural communication that is didactically transformed and designed in order to help university learners:

- $\quad$ deepen their knowledge on cultural universal and specific features of intercultural communication in a globalized world, historical memory and cultural heritage of potential interlocutors, their life styles and communicative styles;

- $\quad$ understand the necessity to accept the principle of dialogue of cultures and civilizations as the major principle of the individual's lifestyle in the world burdened with permanent geopolitical, economic, financial, civilization and cultural conflicts;

- $\quad$ act as a cultural mediator in cross-cultural or intercultural communication;

- $\quad$ acquire effective strategies of cultural education and self-education allowing them to develop themselves as intercultural speakers / writers, effective cultural mediators;

- $\quad$ use effective interactive communicative strategies for academic, professional and other scholar purposes, including those strategies that may be used to overcome cultural barriers destroying professional I business cross-cultural / intercultural communication; 
- $\quad$ understand how to stand up to all forms of modern cultural vandalism (Rozhdestvensky, 1996) and manipulative powers of modern mass media.

\section{Didactic principles of designing pluricultural educational programmes, syllabuses and courses}

The question of principles related to intercultural education is widely discussed in scholarly works in many countries (Byram, Esarte-Sarries,1997; Wadham-Smith;1995 and others), their terminological names, number and methodological interpretation varies from country to country. In Russia and in a number of Eastern European countries within the framework of the sociocultural approach to co-learning languages and cultures (Safonova,1991,1996) such system of principles includes two closely interrelated groups:

- general methodological principles of university learners' pluricultural developments through all the language and cultural Studies courses that are on the university curriculum

and

technological principles of modelling university teaching environment.

Among the first group of principles are such as:

- $\quad$ teaching humanities in the context of dialogue of cultures and civilisations;

environment;

being oriented around the sociocultural context of pluricultural education in a particular learning

- $\quad$ creating didactically appropriate educational space;

education;

developing professionally-oriented and student-centred bilingual / trilingual / plurilingual

- $\quad$ providing competency-based pluricultural education;

Among the second group of principles are the following:

- $\quad$ creating problem-oriented learning environment;

- $\quad$ interdisciplinary collaboration in pluricultural and plurilingual university education;

- $\quad$ designing adequate assessment of learners' intercultural communicative competence.

Within the limits of this paper, it is rather questionable to dwell in detail on each of the principles mentioned above, so I would like to discuss only three of them (principles of teaching humanities in the context of dialogue of cultures and civilisations, creating didactically appropriate educationall space and problemoriented learning environment

The philosophical background for teaching humanities in the context of dialogue of cultures and civilizations is based on Bachtin's dialogism (Bakhtin,1979:293 ) and Kagan's philosophical ideas about the philosophical binary concepts dialogue of cultures - non-dialogue of cultures in human society and communication (Kagan,1988). Kagan in his philosophical work "The World of Communication" discusses three types of relationships between cultures in human society:

- $\quad$ absolutely utilitarian attitude of one culture to the other culture (assimilating a particular culture or adapting it for purely pragmatic utilitarian purposes);

- $\quad$ rejection attitude of one culture towards the other culture / other cultures;

- $\quad$ such relationship between cultures when their representatives demonstrate a mutual intention to develop a cultural understanding, positive intercultural interaction and orientations towards mutual cultural enrichment (Kagan,1988: 213-215). 
The third type of relationship was termed by the author as a dialogue of cultures, whereas the first and the second ones as a non-dialogue of cultures (Kagan,1988: 213-215).It may be of interest to note that the concept of dialogue of cultures is very close in its meaning to the European concept of intercultural dialogue that was introduced in Europe in 2008: ...intercultural dialogue is understood as a process that comprises an open and respectful exchange of views between individuals and groups with different ethnic, cultural, religious and linguistic backgrounds and heritage, on the basis of mutual understanding and respect. It requires the freedom and ability to express oneself, as well as the willingness and capacity to listen to the views of others. Intercultural dialogue contributes to political, social, cultural and economic integration and the cohesion of culturally diverse societies. It fosters equality, human dignity and a sense of common purpose. It aims to develop a deeper understanding of diverse worldviews and practices, to increase cooperation and participation (or the freedom to make choices), to allow personal growth and transformation, and to promote tolerance and respect for the other. (White Paper on Intercultural Dialogue "Living Together As Equals in Dignity", 2008: 17)

The dialogue of cultures as a chosen lifestyle of the individual in his or her cognitive perception of modern communities and in intercultural communication is more than preferable in modern culturally turbulent world, and this lifestyle may be cultivated step-by-step through pluricultural education ) in which Cultural Studies as a university discipline plays one of the major roles in language pedagogy, especially in tertiary language didactics. It is expected to provide:

- an insight into universal characteristics of human culture in general and specific features of different cultures and subcultures, didactically expanding the circle of cultures studied from ethnic to super ethnic (national), from super ethnic to continental cultures and geopolitical formations, without ignoring socially significant subcultures;

- acquisition of skills in sociocultural observations, collecting, systematizing, interpreting and evaluating cultural information necessary for value-oriented cross--cultural or even multicultural analysis that helps to find out what kind of cultural bridges or lack of them is between one's own and other cultures and subcultures;

- a dynamic development of the university learner as a intercultural speaker and mediator with a special focus on cultivating such qualities as sociocultural observation, cultural sensitivity (Holliday, 1994; Stafford et al,1997), cultural openness, cultural readiness to interact with representatives of other cultures, rejection of any cultural snobbery and vandalism, and cultural intelligence (Brett, et al, 2016);

It is quite obvious if we would like to develop an effective intercultural speaker or writer at tertiary educational level, we are to build a graded system of the learner's pluricultural preparation for acting as:

- a cross-cultural observer at A 2 level of the CEFR levels of communicative competences (CEFR, 2001) in everyday communication,

- a cultural communicative ethnographer (Barro et al,1998) and pragmatic anthropologist at CEFR B1 level in everyday and business communication,

- $\quad$ an intercultural mediator at CEFR B2 level in academic communication,

- $\quad$ a translator in bilingual professional communication at CEFR C1 level,

- $\quad$ an interpreter in bilingual professional communication at CEFR C2 level,

- an intercultural facilitator in professional intercultural communication ( the language level is above C2 CEFR level) . 
The principle above goes hand in hand with the principle of creating didactically appropriate educational communicative space, because the first one could hardly be implemented, if the educational space (including communicative space as its inseparable part) is strongly culturally biased, manipulative and authoritarian;

Nowadays educational space include not only innovative classroom and lecture theatre designs, but also the teaching \& leaning practices which are characterized by a particular type of relationship between the teacher and the learner (authoritarian or democratic or liberal), the quality and the suitability of teaching and learning materials for achieving certain educational objectives. In accordance with the principle of creating didactically appropriate educational space, the latter should be thoroughly examined in terms of:

- $\quad$ didactic appropriateness of teaching styles and materials to the learners' private and professional needs as intercultural speakers/writers, their intellectual powers, their communicative powers and abilities, their age characteristics etc.,

- $\quad$ didactic appropriateness of teaching materials for: a) introducing such concepts in the classroom as cultural values, cultural heritage, historical memory and collective cultural memory, cultural heritage, cultural identity, cultural intelligence, cultural barriers and cultural alienation/cringe b) watching, comparing and discussing lifestyles observable in different communities and societies, c) understanding the pitfalls of stereotyped thinking about other cultures that may destroy communication between its interlocutors;

- didactic appropriateness of teaching and learning strategies for developing intercultural skills in: a) identifying cross-cultural barriers and finding out if it is possible and how to overcome them in the situations of intercultural communication); b) identifying the cases of cultural vandalism, communicative aggressiveness and their cultural roots and origins in human civilisations; c) introducing ne's own culture in foreign cultural environments and representing other cultures in local/native environments; d) exploring native and non-native cultures for developing effective cross-cultural / multicultural strategies and finding cultural bridges between different cultures as manifestations of historically bound intercultural links between ethnic and / or national cultures and /or regional and / or continental cultures.

The principle of creating problem-oriented learning environment gives special emphasis to one of the technological aspects of guiding students in their attempts to cultural exploration of globalised world and its entities.

In accordance with this principle pluricultural education should be based mostly on problem -solving tasks and activities involving cognitive, communicative, reflective and evaluative learners' practices and developing their creative powers as intercultural interlocutors. . Minimally, the learners are to do the following tasks

- collect and systematize cultural verbal and non-verbal information;

- compare, interpret the information collected \& systematized,

- $\quad$ evaluate information reliability, cultural value and communicative value for an intercultural speaker;

- interpret and evaluate visual and schematized cultural information (tables, graphs, charts, visual illustrative forms etc.);

- transform verbal cultural information into appropriate visual or schematized forms of information presentation

- reflect on cultural concepts and cultural practices in different language and culture communities;

- $\quad$ explore the linguaculture of verbal texts on one and the same topic within a particular period of time and in such areas as media, academic communication and everyday communication;

- solve culture-bound mathematical problems;

- collect and gather statistics necessary for argumentation in cultural discussions.

These are simplest activities into which students may be involved even in Bachelor Degree programmes. Among the more complex activities are:academic papers and presentations, academic interdisciplinary projects and course works, academic discussions and debates especially on the controversial cultural topics. The latter three activities seem to work well mostly with Master Degree students, though they may be introduced in some simplified forms at the first cycle of higher education in Europe as well. It is worth mentioning that all the cultural activities mentioned 
should form a hierarchical system of cultural activities with a step-by-step increase in their cognitive complexity and oriented towards the zone of students proximal development (L.S.Vygotsky).

Secondly, in accordance with the principle under consideration there should be a change in the educational roles of the educator , because the teacher is more seen here as a facilitator, moderator, coordinator, expert ( but not a bearer of the ultimate truth) and even as an opponent. And though the need for such teaching styles is also strongly felt by Russian university educators, still the authoritarian style of teaching dominates in many Russian university classrooms, and that is not because Russian university teachers would not like to give up an authoritarian style of teaching, but because many of them have not been given many opportunities to practice moderator and facilitator skills, so they need special professional training.

The students educational roles (no matter what profile of their university preparation is) include such as cultural explores (sometimes practical anthropologists), experimenters in the area of cultural sociology and intercultural psychology, intercultural mediators, interpreters, translator and even analysts in some cases).

Thirdly, this principle presupposes also some changes in the form of classroom teacher-student interaction, introducing problem-oriented lectures (including sometimes lectures- provocations at least in Master Degree programmes) and problem-based seminars ( in the form of forums, panel discussions, round-tables, debates etc.)

And all these activities presuppose an integrated interdisciplinary and transdisciplinary approach aiming at developing learners' culture of partnership (including culture of team work and co-operation in the globalised web-based world), academic culture in the intercultural context, culture of professional intercultural communication.

\section{Conclusion}

Cultural Studies as a research field in language pedagogy opens new horizons in examining and developing the university framework for modelling culture-oriented didactic space stimulating university students become competent intercultural speakers. Cultural Studies as a university subject is one of the important means of helping university students step-by step acquire necessary skills for fulfilling modern sociocultural roles from a cultural observer, communicative ethnographer, cultural mediator to an interpreter, translator and cultural facilitator, and in the long run it prepares them for professional intercultural communication. But a didactic success of any Cultural Studies as a university subject for the purposes of participating in intercultural I communication much depends on the principles underlying university courses. Among these principles of vital importance are the principles of teaching and learning languages \& other Humanities in the context of dialogue of cultures and civilisations, creating didactically appropriate educational space and problem-oriented learning environment. But still much has been done in the theory and practice of pluricultural education and in the area of educational experiments in order to compare and make conclusions about the real outcomes of different culture-oriented approaches to university teaching, learning and assessing in different countries and educational establishments And the weakest link here is assessing intercultural or sociocultural competence.

Literature

[1] Bakhtin, M. M. (1979) Problems of Dostoevsky's Poetics. Moscow: Soviet Russia.

[2] Barro, A., Jordan, S., Roberts, C. (1998) Cultural Practice in Everyday Life: the language learner as ethnographer. In Language Learning in Intercultural Perspective / ed. M. Byram \& M. Fleming. - Cambridge: Cambridge University Press, 76-97.

[3] Barro, A. \& Grimm, H. (1998) Integrating language learning and cultural studies: an ethnographic approach to the year abroad . In Integrating New Approaches: The Teaching of French in Higher Education / Ed. by J. A. Coleman \& A. Rouxeville. - London: AFLS / CILT, 1993,1998,147-64.

[4] Bernaus, M. (Ed) (2007) Plurilingual and pluricultural awareness in language teacher education. Strasburg: European Centre for Modern Languages, Council of Europe Publishing

[5] Brady, A. Shinohara, Y. (2000) Principles and activities for a transcultural approach to additional language learning . In System, Volume 28, Issue 2 June 2000,.305-322.

[6] Brett, J., Doz, Y,\& Mever, E.(Ed.) (2016) On Managing Across Cultures. Boston, Massachusetts: Harvard Business Review Press.

[7] Byram, M.(1989) Culture studies in foreign language education.- Clevedon: Multicultural Matters. 
[8] Byram, M., Esarte-Sarries, V.(1991) Investigating Cultural Studies in Foreign Lan?guage Teaching. Clevedon, Philadelphia.

[9] Byram, M., Esarte-Sarries, V. (Ed) (1997)The Sociocultural and Intercultural Dimension of Language Learning and Teaching. Strausburg: Council of Europe Publishing.

[10] Byran, M. \& Flemig, M.(Ed.) (1998) Language Learning in Intercultural Perspective: Approaches through Drama and Ethnography. New York: Cambridge University Press.

[11] Clawson, J.G. (2011) Level Three Leadership: Getting Below the Surface (5th Edition). Harlow: Person Education Limited. 464 Pp.

[12] Common European Framework of Reference: Learning, teaching, assessment/CEFR/ (2001) Cambridge: CUP.

[13] Corbett, J.(2003) An Intercultural Approach to English Language Teaching (Languages for Intercultural Communication and Education). Clevedon, Philadelphia, Adelaide : Multilingual Matters Ltd.

[14] Cultural Intelligence. In J. Brett, Y. Doz \& E. Mever (Ed.) On Managing Across Cultures. Boston, Massachusetts: Harvard Business Review Press, 1-16.

[15] Culturology. XX century. Encyclopedia.(1998) Volume I. Saint Petersburg: University Book, Alyete'ya.

[16] Coste, D., Moore, D. and Zarate, G. (2009) Plurilingual and Pluricultural Competence. Studies towards a Common European Framework of Reference for language learning and teaching. Strasbourg: CE Language Policy Division, Strasbourg.

[17] Hartley, J. (2003). A Short History of Cultural Studies. - London and Thousand Oaks: SAGE Publications Ltd, 200.

[18] Holliday, A. (1994). Appropriate Methodology and Social Context. - Cambridge: CUP.

[19] Kramsch, Cl. (1998) The Privilege of Intercultural Speaker. In Byran,M. \& Flemig, M.(Ed.) Language Learning in Intercultural Perspective: Approaches through Drama and Ethnography. New York: Cambridge University Press, 16-31.

[20] Lado, R. (1957). Linguistics across cultures: Applied linguistics for language teachers. University of Michigan Press.

[21] Meyer, M. Developing transcultural competence: Case studies of advanced language learners // Buttjes, D. \& M. Byram (eds.) Mediating Languages and Cultures: Towards an Intercultural Theory of Foreign Language Education /Edited by D.Buttjes \& M. .Byram . - Clevedon: Multilingual Matters, 1991. -Pp.136-158.

[22] Routledge Encyclopedia of Language Teaching and Learning.(2004) Edited by M. Byram. London and New York Routledge Tailor and Francis Group.

[23] Rozhdestvensky, Yuri.(1969) Typology of the Word. Moscow: Higher School Publishing House, 1969.

[24] Rozhdestvensky, Yuri. (1996) Introduction to the study of culture. Moscow, CheRo.

[25] Safonova, V.(1991) Sociocultural approach to Teaching Foreign Langugaes. Moscow: Higher School Publishing House, Amscort International.

[26] Safonova, V.(1996) Teaching Languages of International Communication in the Context of Dialogue of Cultures and Civilisations, Voronezh: Istoki,1996.

[27] Safonova, V (2001) Cultural Studies in the System of Modern Language Education. In Foreign Languages at School, Number 3, pp.17-24..

[28] Stafford, J.R., Bowman, R., Ewing, T., Hanna, J., \& Lopez-De Fede, A. (1997). Building Culture Bridges. Bloomington, IN: National Educational Service.

[29] Wadham-Smith, N.(1995) British Studies Now.The British Council.

[30] White Paper on Intercultural Dialogue "Living Together As Equals in Dignity" Launched by the Council of Europe Ministers of Foreign Affairs at their 118 th Ministerial Session (2008).Strasbourg Council of Europe F-67075 Strasbourg Cedex http://www.coe.int///dg4/intercultural/source/white\%20paper_final_revised_en.pdf . 